\title{
Why and How Someone Can Be LGBT in Surakarta Residency, Indonesia
}

\author{
Setiadi, Riandini Aisyah, Erna Herawati, Alexandria Firdaus Al-Farisy, Sri Harnani \\ Rafidah Estri, Rizki Luthfia Wardhani, Yudwari Adhicha Nuredis, Burhanudin Ichsan
}

Faculty of Medicine University of Muhammadiyah Surakarta, Indonesia

\begin{abstract}
Sexual orientation refers to sexual attraction relative to man, woman, or both. It has been known since ancient times that some humans engage in sexual activity with same sex. The focus of this research is to know what are the trigger factors that can arouse homosexual orientation in a person in Surakarta residency, Indonesia. This research is a qualitative research using in-depth interview and semi-structured Interviews. The respondents who will be the focus of the study were ten LGBT people with HIV reactive and thirty LGBT people with non-reactive HIV in some non-govermental organizations in Surakarta. Researchers use content analysis techniques that include: 1) data reduction; 2) presentation of data; and 3) drawing conclusions. From the interview, the researchers analyzed qualitatively the research findings. The results show that there are at least 14 trigger factors that can arouse homosexual orientation in a person.
\end{abstract}

Keyword: LGBT, Trigger Factors, Surakarta, Indonesia

\section{INTRODUCTION}

Sexual orientation refers to sexual attraction relative to men, women, or both (Bailey, et al., 2016). It has been known that since ancient times, some humans engage in sexual activity with same sex. In most ancient cultures, local religion and law have played an important role in guiding and advocating approval or disapproval of homosexuality in various contexts. In ancient Greece, some forms of erotic attraction and sexual pleasure between men were accepted as part of cultural norms, and similar forms of close sexual intercourse between men and boys were known as fighters. In some tribes in New Guinea, there is a practice of homosexuality where boys (8-15 years old) are inseminated by adult male fighters. In Crete, every male adolescent has to undergo a homosexual relationship as a rite of passage to adulthood (Dai-Kosi, et al., 2016).

The word homosexual consists of two words, the first being "homo" which means the same, and "sexual" that refers to sexual intercourse, sexual relations. Homosexuality is an emotionally or erotic attraction, either predominantly or exclusively to individuals of the same sex with or without physical contact. Lesbians are terms that describe a woman who is emotionally and physically interested in her fellow women, whereas gay is a term to mention men who sex with men (MSM) as sexual partners, and have an interest in feelings or erotic, both dominant and exclusive and also with or without physical relationship (Putri, 2008). According to MacDonald in (Crooks \& Baur, 2005), bisexual individuals are individuals who can engage and enjoy sexual activity with both sexes, the same sex and different gender, or knowing that they are interested in doing so. While transsexual/transgender is the most widespread term for those who are between two gender, this terminology then evolves into the name of all people who cross gender, not just cross-dresser, hemaprodit even to mention transgender (Kartono, 2009).

People often assume that homosexuality is a mental disorder that causes the sufferer to experience deviation of sexual behavior, but when referring to the DSM IV (Diagnostic Manual of Mental Disorder made by the American Psychiatric Association) homosexual is no longer classified as a mental disorder or other irregularities because it is a requirement of A behavior to be classified as a mental disorder is when the behavior interferes with the life of the sufferer ((Nicolosi in (Wedanthi \& Fridari, 2014)). Then, the $3^{\text {rd }}$ edition in 1980 of DSM APA, homosexuality is classified as an 'egoDystonic homosexuality'and was removed in 1987 (Kang, 2014) (Lee, 2015). 
Various theories and research on the origin of a person to be homosexual has been widely mentioned throughout the world including in Indonesia. The focus of this research is to know what are the trigger factors that can arouse homosexual orientation within a person in Surakarta residency, Indonesia.

\section{OBJECTIVES AND SCOPE OF THE STUdY}

The objectives of the study is to analyzes how is the trigger factors that can arouse homosexual orientation in a person in Surakarta residency, Indonesia.

\section{Methodology}

This research is a type of qualitative research using In Depth, Semi-structured Interviews (IDIs) research design. The study was conducted from March to June 2017. In this study the respondents who will be the focus of the study were ten (10) LGBT people with HIV reactive and thirty (30) LGBT people with non-reactive HIV in some NGOs in Surakarta.

Respondents consisted of 3 non-reactive HIV lesbians, 17 gay men and 4 of whom were HIV reactive, 7 were bisexual and 1 was HIV reactive, and 13 were transgendered with 5 reactive HIV patients. Meanwhile, respondents residing in Surakarta were 32 people with 6 HIV reactive, from Karanganyar 2 people and 1 of them HIV reactive, from Sragen 1 respondent, from Wonogiri 1 respondent and reactive, from Sukoharjo 3 respondents and 2 of them reactive, and 1 respondent comes from Boyolali.

In the context of qualitative research, more precise sample determination is not based on probability sampling technique, this is because qualitative research sees the sampling process as a dynamic population parameter (McMillan \& Schumacher, 2001). So that sampling technique used in this research is purposive sampling.

Researchers use Content Analysis techniques that include: 1) data reduction; 2) presentation of data; and 3) conclusions (Miles, et al., 2014). The course of research is as follows. Researchers went directly to the respondents, the researcher asks respondent to fill in Informed Consent and some other administrative documents, the researcher asks the respondent who is willing to be involved in the research to fill out the questionnaire, and the last one after the respondent complete the questionnaire, the researcher conducts in-depth interviews with all the respondents. From the interview, the researchers analyzed qualitatively the research findings.

\section{Results}

A trigger factors that can arouse homosexual orientation in a person

\subsection{Already Since Childhood Interested in Same-Sex, without Triggered by Trigger, Natural Sexual Orientation}

A total of 10 respondents (25\%) gave information that since childhood he has a sense of attraction with same sex without known cause, just as it is a natural sexual orientation that respondents have:

"From childhood actually I already like the same man, from grade 6 elementary school has started to like, there is no cause, indeed from the childhood already like the men". (Mr. D, Gay)

\subsection{Already Since Childhood, with a Preceded Triggerhomosexual Relationship}

A total of 3 respondents $(7.5 \%)$ said that he became homosexuals due to having sex with same sex when he was a kid:

“Anyway I started to know love after I fell in love with same sex. First time to do anal sex."(Mrs. M, Transgender)

\subsection{Hurt And Traumatized with the Opposite Sex}

Having experience hurt by the opposite sex, to make a person disappointed, angry, hurt, and traumatized have a tendency to take him or her in homosexual orientation. This can happen because someone whose heart is hurt by the opposite sex, then he will tend to run away to same-sex couples in meeting sexual and sexual needs. Number of respondents who became homosexual with reasons of hurt and trauma with the opposite sex numbered 5 people (12.5\%): 
"Yes because it hurt. Initially it's my wife cheating in front of my eyes, it's immediately hurt."(Mr. M, Gay)

"Because I no longer trust a men, my husband's mother who was number 2 was rude, always quarreled with me. Then I've got a boyfriend, rough, too, since I no longer believe in men, trauma."(Mrs. N, Lesbian)

\subsection{Economic Reasons, Selling Themselves to Same-Sex}

The economy turned out to be one of the causes that could trigger a person to become homosexual, 4 respondents $(10 \%)$ had the same reasons:

"When I was in high school I had a girlfriend, I became homosexual because I needed money, identical with paid, since then I resigned willing to anal, oral, that's where I deepen the character of being homosexual."(Mr. U, Bisexual)

\subsection{Psychic Trauma Caused by Homosexual Pedophilia Victims}

Pedophilia behavior can leave a deep psychic trauma on the victim, on the behavior of homosexual pedophilia, the incident can be the main cause of the victim to be homosexual, 3 respondents $(7.5 \%)$ said had been victims of homosexual pedophilia when he was a child, and the perpetrator Is the victim's uncle, an elementary school teacher, as well as other adults who the victims know:

"From my own elementary school teacher, I was playing near his house, then I was given a pocket money, after that I was invited to play and I was asked to play his genitals, I was also asked to oral his cock, in the end I still until now still like the men." (Mrs. I.A, Transgender)

\subsection{Victims of Homosexual Harassment}

In addition to childhood, homosexual abuse experienced by adolescents or adults can also leave marks and foster homosexual orientation in the victim, 1 respondent $(2.5 \%)$ gave information:

"From college, I was the victim of homosexual harassment, then I was drunk, then I was orally, so yeah, if Im story like this seems like I want to cry."(Mr. J, Biseksual)

\subsection{Curious How it Feels to be Homosexual}

A person's curiosity about homosexual behavior can trigger the person to become homosexual, 2 respondents $(5 \%)$ have that curiosity:

"I have just become LGBT for five years, the reason is because I want to find a new sensation, want to feel what it's like to have sex with same sex."(Mr. K, Gay)

\subsection{Environmental Factor}

Often playing with the opposite sex, playing a toy belonging to the opposite sex, feeling himself the opposite sex (Childhood Gender Nonconformity)

From the findings obtained in this study, the environment is the biggest trigger factor that can arouse homosexual orientation in a person. Often play with the opposite sex as a child contributes the number of $17.5 \%$ (7 respondents):

"I became LGBT since childhood, because I often play with girls, because my environment is mostly playing with girls, so from kindergarten, elementary, junior high school thats all girls, play cooking, play dolls, jump rope, ah It's just like that all girl's toys, the tendency to play a lot of girls continue to be attracted to boys." (Mr. C, Bisexual)

\subsection{Frequently Gathered with the Homosexual Community}

Frequent gatherings with the LGBT community can also have an effect on a person's homosexual orientation. A total of 2 respondents (5\%) gave information:

"But to be a direct transgender get together with friends transvestites, since graduating junior high school."(Mrs. F1, Transgender)

\subsection{All Siblings in a Family of the Opposite Sex}

Being the only child of a certain sex (male / female) in the family and having a brothers or sisters who is entirely different sex also provides a role for the tendency to be homosexual. One respondent $(2.5 \%)$ gave information:

"From childhood, maybe from family environmental factors because in my family all women."(Mr. D.A, Gay) 


\subsection{Since Childhood the Family Often Provide Toys Belonging to the Opposite Sex to the Child}

The role of the family in educating children in childhood also has an effect on their sexual orientation. One respondent $(2.5 \%)$ said:

"I was from childhood because of the association, because the environment, and by my family is always playing with women's toys, then yes it seems that from my family is very supportive when I play with women."(Mrs. W, Transgender)

\subsection{Have a Broken Home Family}

Having a broken home family can have a negative effect on the child, one of which is the effect on his or her sexual orientation. A child that born in a broken home family has a great chance to get the attention and affection he never gets from both parents to others. The number of broken home respondents amounted to 1 person $(2.5 \%)$ :

"Family factor, I come from broken home family, I just stay with grandma and grandfather, my mother did not take care of me, and my father is sick, and I do not get the affection from father, often play with girls too, family factor as well." (Mr. C, Bisexual)

\subsection{The Dominance of Only One Parent in Family (Close-Binding-Intimate)}

The attitude of parents in educating children in childhood can have an influence on the child's psychic development. If there is only one parent who dominates in the family, this can be a trigger change in the sexual orientation of the child. Respondents who in their childhood received a hard instruction from one parent amounted to 1 person $(2.5 \%)$ :

"At that kindergarten I was already impressed with men, because maybe my mother's factor was harder than father, so the father was more compassionate, if my mother often scolded me, I was wrongly scolded, at that time I feel more comfortable if Near the father.” (Mr. H, Gay)

\subsection{Less Attention and Affection from Parents}

Parental concern and affection is very important in supporting the growth of the child. Respondents who received less attention and affection from their parents amounted to 1 person (2.5\%):

\section{“Lack of attention and affection from parents, from elementary already like men.”(Mr. R, Gay)}

\section{DisCUSSION}

According to (Sheldon, et al., 2007) there are two main categories of scientific explanations that have been proposed to explain the origin of homosexuality: (1) biologically; And (2) psychosocial. The proposed biological theory suggests that Klinifelters syndrome, characterized by an additional female chromosome, may affect some individuals against homosexuality. Based on this assumption some people argue that homosexuals are women in the male body ( (Lang, 1968) in (Nyarenchi, 2004)).

In 1993, another biological theory of the origin of homosexuality in a man has been proposed by Hamer et al, who in his study found evidence that a form of homosexuality in males is more dominantly transmitted through the mother's side and genetically related to the Xq28 chromosome region. The Xq28 chromosome contains genes that contribute to homosexual orientation in men, which then is called "Linkage Study" (Hamer, et al., 1993). Nevertheless, the "Linkage Study" proposed by Hamer et al gained a lot of opposition from other researchers. George Rice et al, writing in Science, notes that evidence for the linkage of the X chromosome has been questioned theoretically and empirically. Most would agree that the homosexual orientation of men is not a simple Mendelian nature. There will be strong selective pressure on such genes. Hamer et al identification of the contribution of genes approaching Xq28 to homosexuality in some families selected for X-linked transmission of these properties may be fraught with type 1 (false positive) errors. This is important to consider, given the inability of multiple linkage reports for complex behavioral properties (Rice, et al., 1999).

Other researchers reported that there was a relationship between prenatal hormonal imbalance and the incidence of lesbianism in women. This is evidenced by interviewing women who have congenital adrenal hyperplasia $(\mathrm{CAH}), \mathrm{CAH}$ is a chronic endocrine disorder that exposes the patient to abnormal androgen levels during prenatal periods comparable to that of men. In the study, the results obtained during women's gestation with CAH reported more response to bisexual or homosexual than control group women (Bem, 1996). 
Although there is much debate and disagreement between researchers related to homosexuality is a hereditary and genetically inherited sexual orientation, but in this study the researchers found findings similar to previous research. A total of 10 respondents $(25 \%)$ interviewed by the researcher gave information that since childhood he has a sense of attraction with same sex without the original cause, like it is natural sexual orientation owned by the respondent since birth.

In addition to the biological factors that have been described, psychosocial factors are the most important factor and the most important role in generating homosexual orientation in a person. According to (Bailey \& Zucker, 1995)childhood gender nonconformity, behave like other sexes, have a strong correlation with the formation of sexual orientation in adults. More specifically, childhood gender nonconformity in boyhood consist of the following phenomenon: cross-dressing, wanting to have a long hair, playing with dolls, dislike competitive sports and playing rough, preferring girls as playmates, showing increased levels the anxiety of separation, and the desire to be or believe that he is a woman. In girls, childhood gender nonconformity consist of dressing like and playing with boys, showing interest in competitive sports and playing rough, lacking interest in conventional female toys such as dolls and makeup, and wanting to be boys. Gross childhood incompatibility usually occurs at preschool age (Bailey, et al., 2016). This is very much in line with what researchers get in the research.

Pranata conduct research in Samarinda city to know behavior and social reality of gay life in Samarinda city and get result of social deviant behavior happened because two factor, that is internal factor where gay psychological condition and its orientation to same kind become trigger person become gay, and external factor where the environment or things that deeply imprint such as getting indecent abuse in childhood (becoming a victim of pedophilia) can be a trigger for a person to become homosexual (Pranata, 2015). The same is also reported by Lestari, that the reasons for choosing a homosexual way of life are: 1) the sexual needs which are perceived by homosexuals or gays can only be attracted to fellow men alone, 2) the trauma of love with the opposite sex is felt enough In the male by choosing the same pair with the hope of the pain not being repeated and 3) the unpleasant sex experience (sodomy) resulted in a prolonged trauma that eventually made what he experienced as a sexual experience and continued for a long time (Lestari, 2012).

A study in the Journal of Sex \& Marital Therapy in 1997 examined sexual experiences, sexual thoughts, and past fantasies about sexual contact of 35 adult men who were sexually abused during their childhood. The study found that among men, a history of homosexual abuse in childhood was associated with their homosexual orientation when adults and sexual attraction to children. In this study, 46 percent of abused men, compared with 12 percent of non-abusive men, defined their sexual orientation as bisexual or homosexual. Therefore, these findings further validate previous research on the sexual orientation of children who have been sexually abused (Bramblett, Jr. \& Darling, 1997). The study concludes with these findings, it appears that sexual abuse as a child may affect adult male tendencies to fantasize about young men and make them homosexual (Bramblett, Jr. \& Darling, 1997) (Van den Aardweg, 2011).

In another study, The Menninger Clinic Bulletin mentions "seduction" among other lists of childhood experiences that may contribute to same-sex attraction. There are a number of factors that occur in childhood that seem to be related to the development of their homosexuality as adults. Conditions such as 1) prolonged segregation of sex; specific, highly stimulating, and satisfying in homosexuality; 2) seduction by adult homosexuals; and 3) a threatening and painful experience with respect to sex games or relationships with the opposite sex. These factors and related factors in childhood and adolescence correlate with the occurrence of adult homosexuality (Brown, 1963). In this study, researchers also get the same results with research that has been previously published. That being a victim of homosexual pedophilia, having a bad experience and heartache with a partner of the opposite sex, as well as being a victim of homosexual harassment is a triggering factor that a person may become homosexual.

As has been found in other studies, family is one factor that can affect someone sexual orientation's. Bieber et al., In his book "Homosexuality : A Psychoanalytical Study" suggests that the 'classical' triangular pattern of homosexual causes is: 1) the pattern by which a close-binding-intimate (CBI) mother with a boy; 2) mothers who dominate and 3) minimize husbands who are separate fathers, especially unfriendly fathers (Bieber, et al., 1962). From these statistical analyzes, it is likely that every child exposed to this combination of parents will either become homosexual or develop severe homosexual problems (Bieber, et al., 1962) (Siegelman, 1974) (Brown, 1963) (O'Connor, 1964) 
(Braaten \& Darling, 1965). The existing theory is slightly different from the results obtained by researchers in this study. In this study, researchers get data of one respondent who experienced CBI situation in his family. However, if in another study a mother dominates the family and father's role is lost and indifferent to his child, but in this study obtained data that the mother dominates in the family by being tough on her son, and the father just closer and loving his son. This is what makes him even more admiring the figure of a father because it feels more secure and comfortable than with his mother. And that also makes the child more admiration with men than women.

Limitations in this study is the first, the lack of time owned by researchers in conducting in-depth interviews to respondents because the respondents have to work and have other busy. So there may be other information that has not been presented by the respondent to the researcher. Secondly, none of the respondents came from Klaten District who were involved in the study.

Apart from these limitations, this study has the following advantages: (1) the sample (respondents) involved in the research amounted to a lot (40 people) and has met the criteria of qualitative research sampling, (2) the respondent's distribution of the respondents involved in the research is almost from the entire Surakarta Residency so that it can be a representation for the surrounding area, (3) there are respondents with Reactive HIV diagnosis who are willing to engage in research, and (4) respondents in this research are expected to be able to fulfill and represent various aspect in life of LGBT community in Surakarta Residency - Indonesia.

\section{Conclusion}

Based on the findings obtained in this study, researchers draw the conclusion that homosexuality is a complex component to be able to find the main cause. There is no single cause that can stand alone in causing a person to be homosexual. Factors that researchers find in generating homosexual orientation within a person are mutually supportive and refine the other factors. Both biological, psychosocial factors, pedophilia victims, family roles, friends gathered, even the economy are all components that can not stand alone in generating homosexual orientation. All components are mutually sustainable.

From this study, researchers can also conclude that homosexuality is not something that can 'spread' to just anyone. A person who has experienced homosexual abuse will not be a homosexual if there is no "homosexuality" in him. After experiencing such harassment, if $\mathrm{He}$ is a true heterosexual then later he will become afraid of homosexual men and choose to avoid it, not the opposite. This conclusion is similar to the Stekel in (Barrett, 2014) which states that everyone is bisexual and can be conditioned depending on one's personal and psychological experience.It's just that researchers do not agree if it is said that everyone is bisexual, from this research that researchers get is every homosexual previously is bisexual whose him or her 'homosexual side' is still asleep, because gained experience exposed by various trigger factors that researchers found in this study, the 'homosexuality side' who had previously 'fallen asleep' to rise up and cause the person to become homosexual.

\section{ACKNOWLEDGMENTS}

First, we would like to thank Allah S.W.T for giving us the opportunity and the pleasure to complete this research. Furthermore, we would like to thank the Ministry of Research and Technology of Higher Education of the Republic of Indonesia (Kemenristekdikti) which has funded this research. We also give thanks to the Gaya Mahardhika Foundation for participating in this research as a contact between researchers with the 40 respondents willing to be involved in the research. Gaya Mahardhika Foundation is one of the institutions engaged in public health, empowerment, and mentoring People with HIV / AIDS (PLWHA) in Central Java Province, Indonesia. To the Dean of Faculty of Medicine, University of Muhammadiyah Surakarta, we thank you for supporting and providing maximum facilities for us to do this research. And the last but not least, we thank dr.Burhannudin Ichsan.,M.Med.Ed.,M.Kes who has provided a great help from the beginning of this study began until this research was completed as a qualified lecturer in qualitative research.

\section{REFERENCES}

[1] Bailey, J. M. et al., 2016. Sexual Orientation, Controversy, and Science. SAGE, 17(2), pp. 45101.

[2] Bailey, J. M. \& Zucker, K. J., 1995. Childhood sex-typed behavior and sexual orientation: A conceptual analysis and quantitative review. Developmental Psychology, Volume 31, pp. 43-55.

[3] Barrett, J., 2014. Misusing Freud: Psychoanalysis and the Rise of Homosexual Conversion Therapy. Psi Sigma Siren, 8(1), pp. 3-14. 
[4] Bem, D. J., 1996. Exotic Becomes Erotic : A Developmental Theory of Sexual Orientation. American Psychological Association, 103(2), pp. 320-335.

[5] Bieber, I. et al., 1962. Homosexuality: A Psychoanalytic Study of Male Homosexuals. United States: Vintage Books.

[6] Braaten, L. J. \& Darling, D. C., 1965. Overt and Covert Homosexual Problems Among Male College Students. Genetic Psychology Monographs, Volume 71, pp. 302-302.

[7] Bramblett, Jr., J. R. \& Darling, C. A., 1997. Sexual Contacts : Experiences, Thoughts, and Fantasies of Adult Male Survivors of Child Sexual Abuse. Journal of Sex \& Marital Therapy, 23(4), p. 313.

[8] Brown, D., 1963. Homosexuality and Family Dynamics. s.1., Bulletin of the Menninger Clinic.

[9] Brown, D. G., 1963. Homosexuality and Family Dynamics. Bulletin of the Menninger Clinic, 27(5), pp. 229-230.

[10] Crooks, R. \& Baur, K., 2005. Our Sexuality. China: Thomson Wadsworth.

[11] Dai-Kosi, A. D., Asamani, L. \& Adomako, B., 2016. Ghanaian Perspectives on the Present Day Dynamics of Homosexuality. African Research Review, 10(5), pp. 1-12.

[12] Hamer, D. et al., 1993. A linkage between DNA markers on the X chromosome and male sexual orientation. Science, 261(5119), pp. 321-327.

[13] Kang, H. S., 2014. The Effect of High School Student's Perception of Parental Child-Rearing Attitude on Their Attitude on Their Attitude toward Homosexuality : The Mediating Effect of Authoritarian Personality, Seoul: Chung-Ang University.

[14] Kartono, K., 2009. Psikologi Abnormal Dan Abnormalitas Seksual. 7 penyunt. Bandung: CV Mandar Maju.

[15] Lang, T., 1968. Studies In the Genetic Determination of Homosexuality. New York: Grone and Stratton.

[16] Lee, M.-R., 2015. Analysis on the Theology Research of Homosexuality in Korea. International Journal of Bio-Science and Bio-Technology, 7(6), pp. 151-162.

[17] Lestari, G., 2012. FENOMENA HOMOSEKSUAL DI KOTA YOGYAKARTA, Yogyakarta: UNIVERSITAS NEGERI YOGYAKARTA.

[18] McMillan, J. H. \& Schumacher, S., 2001. Research In Education a Conceptual Introduction. 5 penyunt. New York: Addison Wesley Longmen Inc..

[19] Miles, M., Huberman, A. \& Saldana, J., 2014. Qualitative Data Analysis, A Methods Sourcebook. 3 penyunt. USA: Sage Publications.

[20] Nyarenchi, M. K., 2004. A THEOLOGICAL ETHICAL ASSESSMENT OF HOMOSEXUALITY IN THE EAST AFRICAN CONTEXT : "A SEVENTH-DAY ADVENTIST PERSPECTIVE", Africa: University of Pretoria.

[21] O'Connor, P. J., 1964. Aetiological Factors in Homosexuality as Seen in Royal Air Force Psychiatric Practice. British Journal of Psychiatry, Volume 110, pp. 384-385.

[22] Pranata, T. D., 2015. PERILAKU DAN REALITAS SOSIAL KEHIDUPPAN GAY DI KOTA SAMARINDA. eJournal Sosiatri-Sosiologi, 3(3), pp. 135-150.

[23] Putri, S., 2008. Proses Coming Out Pada Gay.

[24] Rice, G., Anderson, C., Risch, N. \& Ebers, G., 1999. Male Homosexuality: Absence of Linkage to Microsatellite Markers at Xq28. Science, Volume 284, p. 666.

[25] Sheldon, J. P. et al., 2007. Beliefs About the Etiology of Homosexuality and About the Ramifications of Discovering Its Possible Genetic Origin. Journal of Homosexuality, Vol. 52((3/4)), pp. 111 - 150.

[26] Siegelman, M., 1974. Parental Background of Male Homosexuals and Heterosexuals. Archives of Sexual Behavior, Volume 3, pp. 3-4.

[27] Van den Aardweg, G. J., 2011. Abuse by Priests, Homosexuality, Humanae vitae, and a Crisis of Masculinity in the Church. The Linacre Quarterly, 78(3), pp. 274-293.

[28] Wedanthi, P. H. \& Fridari, I. G. A. D., 2014. Dinamika Kesetiaan Pada Kaum Gay. Jurnal Psikologi Udayana, 1(2), pp. 363-371 